\title{
The role of SPECT-DaTSCAN in the diagnosis of isolated tremor syndromes
}

\section{Rola SPECT-DaTSCAN w diagnostyce izolowanego drżenia}

\author{
1 Department of Extrapyramidal Diseases, Medical University of Lodz, Łódź, Poland \\ ${ }^{2}$ Department of Nuclear Medicine, Medical University of Lodz, Łódź, Poland \\ ${ }^{3}$ Department of Quality Control and Radiological Protection, Medical University of Lodz, tódź, Poland \\ Correspondence: Agata Gajos, MD, PhD, Department of Extrapyramidal Diseases, Medical University of Lodz, Central University Hospital, Pomorska 251, 92-213 Łódź, Poland, \\ e-mail: agata.gajos@umed.lodz.pl \\ Drn. med. Agata Gajos, Klinika Chorób Układu Pozapiramidowego, Uniwersytet Medyczny w Łodzi, Oddział Dzienny, Poradnia Neurologiczna, Centralny Szpital Kliniczny w Łodzi, ul. Pomorska 251, 92-213 Łódż, \\ tel.: +48422725744/45, e-mail: agata.gajos@umed.lodz.pl
}

\begin{abstract}
Objectives: The purpose of our study was to determine the probability of developing Parkinson's disease in various syndromes of isolated tremor. Material and methods: We performed a retrospective analysis of the diagnostic process in patients with isolated upper limb tremor where single-photon emission computed tomography (SPECT)-DaTSCAN was performed. Twenty-four consecutive subjects ( 9 males, 15 females) with isolated tremor of one or both upper limbs were studied. The patients were referred for SPECT by neurologists from various centres. Cases of diagnosed structural, metabolic or druginduced tremor were not included in the study. All patients were examined by a movement disorder specialist before and 1-3 years after SPECT-DaTSCAN. All subjects were classified according to the Consensus Statement on the Classification of Tremors (2018). Results: The lowest probability of developing Parkinson's disease was found in patients with rest and action (postural and kinetic) tremor, both unilateral and bilateral. The risk was also low in subjects with postural and kinetic tremor. In cases of a combination of rest and postural tremor (both unilateral and bilateral), the likelihood of neurodegenerative parkinsonism was high. Conclusion: Performing SPECT-DaTSCAN in selected cases of isolated of tremor with a high probability of Parkinson's disease avoids the unnecessary use of drugs recommended in the therapeutic algorithms applicable in essential tremor.
\end{abstract}

Keywords: isolated tremor syndromes, SPECT-DaTSCAN, probability of Parkinson's disease

Streszczenie Cele: Celem pracy była ocena ryzyka rozwinięcia się choroby Parkinsona w różnych postaciach drżenia izolowanego. Materiał i metody: Przeprowadzono retrospektywną analizę procesu diagnostycznego u pacjentów z izolowanym drżeniem kończyn górnych, u których wykonano badanie SPECT-DaTSCAN. Badaniem objęto grupę 24 kolejnych pacjentów (15 kobiet, 9 mężczyzn) z izolowanym drżeniem jednej lub obu kończyn górnych. Pacjenci byli kierowani na SPECT-DaTSCAN przez neurologów z różnych ośrodków. Do badanej grupy nie włączono osób ze stwierdzonymi zmianami strukturalnymi, metabolicznymi oraz przypadków drżenia polekowego. Wszyscy pacjenci byli badani przez specjalistę zaburzeń ruchowych przed badaniem SPECT-DaTSCAN i ponownie 1-3 lata później. Badane osoby były klasyfikowane zgodnie z opublikowanym w 2018 roku Consensus Statement on the Classification of Tremors. Wyniki: Najniższe ryzyko rozwinięcia się choroby Parkinsona stwierdzono w grupie chorych z współistniejącym drżeniem spoczynkowym i action tremor (posturalnym i kinetycznym), zarówno jedno- jak i obustronnym. Było ono także niskie u pacjentów ze współistnieniem drżenia posturalnego i kinetycznego. W przypadkach połączenia drżenia spoczynkowego i posturalnego prawdopodobieństwo parkinsonizmu neurozwyrodnieniowego było wysokie. Wnioski: Wykonywanie badania SPECT-DaTSCAN u wybranych pacjentów z izolowanym drżeniem z wysokim prawdopodobieństwem choroby Parkinsona pozwala uniknąć w tych przypadkach niepotrzebnego stosowania leków zalecanych w algorytmach terapeutycznych drżenia samoistnego.

Słowa kluczowe: zespoły izolowanego drżenia, SPECT-DaTSCAN, ryzyko choroby Parkinsona 


\section{INTRODUCTION}

$\mathrm{T}$ remor is the most common form of movement disorder. It may be the only manifestation throughout the course of the disease, as it is in essential tremor (ET). Isolated tremor may also precede the occurrence of other symptoms of the disease, e.g. in Parkinson's disease (PD) or dystonias. The analysis of the clinical presentation is crucial in the differential diagnosis of tremor disorders. However, the overlapping of clinical features may hinder this process, in some cases to a large extent. For example, the same combination of activation conditions (e.g. rest and postural tremor or rest and kinetic tremor) can be observed in both PD and ET (Albanese et al., 2013; Deuschl et al., 1998; Louis, 2014). The diagnostic approach based on two axes, clinical and aetiological, is proposed in the recently published Consensus Statement from the MDS Task Force on Tremor (Bhatia et al., 2018).

${ }^{123} \mathrm{I}$-ioflupane ${ }^{123} \mathrm{I}$-fluoropropyl CIT, ${ }^{123} \mathrm{I}$-FP-CIT, DaTSCAN $^{\oplus}$, GE Healthcare) is a dopamine transporter (DAT) radioligand for single-photon emission tomography (SPECT). According to the EFNS/MDS-ES recommendations, SPECT-DaTSCAN can be performed as part of differential diagnosis of degenerative parkinsonism and ET (Level A) and, more specifically, in the presence of atypical tremor syndromes (Berardelli et al., 2013). SPECT-DaTSCAN is normal in ET, whereas in PD and in other neurodegenerative parkinsonian syndromes (PS) the reduced tracer uptake within the striatum reflects the loss of dopaminergic neurons in the substantia nigra (Kim et al., 2002; Marshall and Grosset, 2003; Perju-Dumbrava et al., 2012; Vlaar et al., 2008).

The purpose of our study was to determine the probability of developing PD in various syndromes of isolated tremor.

\section{MATERIAL AND METHODS}

\section{Patients}

Twenty-four subjects ( 9 males and 15 females) with isolated tremor of one or both upper limbs were selected from a database of consecutive 108 patients, who have been evaluated using SPECT-DaTSCAN in 2015-2017 at the Department of Nuclear Medicine, Medical University of Lodz, Poland. The patients were referred for SPECT by neurologists from various centres. Cases of diagnosed structural, metabolic or drug induced tremor were not included in the study.

All patients were examined by a movement disorder specialist (AG or $\mathrm{AB}$ ) before and $1-3$ years after SPECT-DaTSCAN.

\section{SPECT-DaTSCAN}

SPECT/computed tomography (CT) acquisitions were performed with double-head hybrid gamma-camera Infinia Hawkeye GE $4 \mathrm{~h}$ after i.v. administration of $5 \mathrm{mCi}$
123I-DaTSCAN. Prior to radiotracer injection, patients received oral potassium iodine (Lugol's solution) to block thyroid uptake of free radioactive iodide. Data were acquired with use of low energy high resolution (LEHR) collimators in dual energy window: $159 \mathrm{keV} \pm 10 \%$ (scatter: $130 \mathrm{keV} \pm 10 \%$ ), in $128 \times 128$ matrix. In a step-and-shoot method, 120 projections for $45 \mathrm{~s}$ each were registered with the use of zoom equal to 1.5. Images reoriented to orbitomeatal plane were reconstructed with the OSEM method (2 iter., 10 sub., postfilter: Butterworth 0.50/10) with scatter correction and attenuation correction based on CT attenuation maps.

The analysed SPECT-DaTSCAN variables were ${ }^{123}$ I-ioflupane uptake ratios in the entire striatum, putamen and caudate in both hemispheres. The quantitative assessment of DaTSCAN-SPECT images was made using DaTQUANT delivered by GE Healthcare.

The study was retrospective and all data obtained were the result of routine clinical evaluation of patients. Therefore, it was not necessary to apply for approval from the Ethics Committee.

\section{RESULTS}

\section{Group A: the patients with normal SPECT-DaTSCAN}

The group included 17 patients (5 males, 12 females) aged 39-72 (mean: 58 years of age).

Ten patients (Tab. 1, Group I; 3 males, 7 females), aged 42-72 (mean: 64), presented bilateral asymmetrical rest tremor; however, kinetic (simple and intention) and postural tremor was dominant. In 6 patients, the history of tremor was shorter than 3 years, while in 4 others it did not exceed 5 years. The next 4 patients (Group II; 2 males, 2 females), aged 59-70 (mean: 62.2), showed bilateral asymmetrical postural and kinetic tremor for 1-2 years; no resting tremor was observed.

All patients reported no improvement after alcohol. In 6 patients, no effect after levodopa administration was observed, while in 6 remaining subjects levodopa was not used or was discontinued after a few days due to side effects. All 14 patients were examined by a neurologist after 1-3 years from the DaTSCAN-SPECT study, and no neurological signs were found except for tremor.

Three other (Group III) female patients (aged 37-47, mean: $41)$ with a 1-2-year history of one-sided kinetic (postural and intention) tremor declared subjective improvement after levodopa. One of them had a 9-year-old son with a 2-year history of foot dystonia. Two years after the SPECT study, the parent developed dystonic movements in the upper limb affected by tremor and bradykinesia in both extremities on the same side. In 2 other subjects (one of them reported a 17-year history of PD in her mother), neurological re-evaluation did not reveal new symptoms and the pattern of their tremor remained unchanged. 


\begin{tabular}{|c|c|c|c|c|c|c|c|c|}
\hline Group & Patients & $\begin{array}{l}\text { Clinical features of } \\
\text { tremor (Bhatia et al., } \\
\text { 2018) before referring } \\
\text { for SPECT-DaTSCAN }\end{array}$ & $\begin{array}{l}\text { Distribution } \\
\text { bilateral/ } \\
\text { unilateral }\end{array}$ & $\begin{array}{l}\text { History } \\
\text { of tremor } \\
\text { (years) }\end{array}$ & $\begin{array}{l}\text { Family history } \\
\text { of movement } \\
\text { disorders }\end{array}$ & $\begin{array}{l}\text { Improvement } \\
\text { of tremor after } \\
\text { levodopa (before } \\
\text { DaTSCAN) }\end{array}$ & $\begin{array}{l}\text { Result of } \\
\text { SPECT-DaTSCAN }\end{array}$ & $\begin{array}{l}\text { Clinical } \\
\text { diagnosis }\end{array}$ \\
\hline I & $\begin{array}{l}7 \text { females, } \\
3 \text { males, } \\
\text { aged } 42-72 \\
\text { (mean 64) }\end{array}$ & $\begin{array}{l}\text { Rest + action } \\
\text { (postural + kinetic) }\end{array}$ & Bilateral & $\begin{array}{l}>3 \text { years - } \\
6 \text { subjects } \\
<3 \text { years - } \\
4 \text { subjects }\end{array}$ & $\begin{array}{l}3 \times \text { positive } \\
(1 \times \text { tremor } \\
\text { in mother, } \\
1 \times \text { tremor in father, } \\
1 \times \text { tremor } \\
\text { in grandmother }) \\
7 \times \text { negative }\end{array}$ & $\begin{array}{l}\text { No improvement - } 6 \\
\text { Non-treated - } 4\end{array}$ & \multirow[t]{2}{*}{ Normal } & \multirow[t]{2}{*}{ ET } \\
\hline$\|$ & $\begin{array}{l}2 \text { females, } \\
2 \text { males, } \\
\text { aged } 59-70 \\
\text { (mean 62) }\end{array}$ & $\begin{array}{l}\text { Postural + kinetic } \\
\text { (simple + intention) }\end{array}$ & Bilateral & All $<3$ years & $\begin{array}{l}2 \times \text { positive } \\
(2 \times \text { tremor } \\
\text { in mother }) \\
2 \times \text { negative }\end{array}$ & $\begin{array}{l}\text { No improvement - } 1 \\
\text { Non-treated - } 3\end{array}$ & & \\
\hline \multirow[t]{3}{*}{ III } & $\begin{array}{l}\text { Female, } \\
\text { aged } 37\end{array}$ & \multirow[t]{3}{*}{$\begin{array}{l}\text { Postural + kinetic } \\
\text { (simple + intention) }\end{array}$} & \multirow[t]{3}{*}{ Unilateral } & \multirow[t]{3}{*}{ All $<3$ years } & Dystonia in son & $\begin{array}{l}\text { Subjective } \\
\text { improvement }\end{array}$ & \multirow[t]{3}{*}{ Normal } & $\begin{array}{l}\text { Dystonic } \\
\text { tremor+ } \\
\text { bradykinesia }\end{array}$ \\
\hline & $\begin{array}{l}\text { Female, } \\
\text { aged } 39\end{array}$ & & & & No & $\begin{array}{l}\text { Subjective } \\
\text { improvement }\end{array}$ & & $\begin{array}{l}\text { Indeterminate } \\
\text { tremor }\end{array}$ \\
\hline & $\begin{array}{l}\text { Female, } \\
\text { aged } 47\end{array}$ & & & & PD in mother & $\begin{array}{l}\text { Subjective } \\
\text { improvement }\end{array}$ & & $\begin{array}{l}\text { Indeterminate } \\
\text { tremor }\end{array}$ \\
\hline IV & $\begin{array}{l}2 \text { males, } \\
\text { aged } 51 \\
\text { and } 63\end{array}$ & $\begin{array}{l}\text { Rest + action } \\
\text { (postural + kinetic) }\end{array}$ & $\begin{array}{l}\text { Unilateral -1 } \\
\text { Bilateral -1 }\end{array}$ & All $<3$ years & No & No improvement - 2 & Abnormal & $\begin{array}{l}\text { Tremor } \\
\text { dominant PD }\end{array}$ \\
\hline \multirow[t]{2}{*}{ V } & $\begin{array}{l}3 \text { females, } \\
1 \text { male, } \\
\text { aged } 46-76 \\
\text { (mean 59) }\end{array}$ & \multirow[t]{2}{*}{ Rest + postural } & $\begin{array}{l}\text { Unilateral - } 1 \\
\text { Bilateral -3 }\end{array}$ & All $<3$ years & No & $\begin{array}{l}\text { No improvement - } \\
\text { all }\end{array}$ & \multirow[t]{2}{*}{ Abnormal } & PD \\
\hline & $\begin{array}{l}\text { Male, } \\
\text { aged } 46\end{array}$ & & Bilateral & 1 year & No & No improvement & & Possible MSA \\
\hline
\end{tabular}

Tab. 1. Clinical characteristics of the studied group of patients

\section{Group B: the patients with abnormal SPECT-DaTSCAN}

There were 4 male and 3 female patients aged 44-76 (mean: 56) in this group.

Tree females and 1 male (Group IV), aged 46-76 (mean: 59,0), had a 1.5-2-year history of bilateral asymmetrical or unilateral postural tremor that did not respond to levodopa. Several months after SPECT, they developed bradykinesia and rigidity which responded well to levodopa, and it was possible to diagnose PD according to the UK Brain Bank Criteria.

Two years after SPECT, a 44-year-old male patient (Group V) with a one-year history of bilateral asymmetrical tremor developed urinary incontinence, orthostatic hypotonia as well as bradykinesia with rigidity, which were resistant to levodopa. A diagnosis of possible MSA was made (Gilman et al., 2008; Stankovic et al., 2014).

The dominant rest and postural tremor and poorly expressed rest tremor were observed unilaterally in a 51-year-old male subject (3-year history of tremor) and bilaterally in another male patient (aged 63, 2-year history still presented isolated unilateral tremor, and no other parkinsonian signs were observed. Tremor-dominant PD was diagnosed. In the second subject, bilateral bradykinesia and rigidity were found after two years, and they responded well to levodopa. Because the severity of kinetic tremor increased at the same time, the coexistence of ET could not be ruled out in our opinion.

\section{DISCUSSION}

Tremor is the most common form of movement disorder. The list of tremor syndromes is long, and the list of diseases that may manifest with tremor is even longer. The correct evaluation and classification of a patient's tremor is the first and very important step in the diagnostic pathway. Relatively often, the diagnosis of tremor requires differentiation with PS. In such cases SPECT-DaTSCAN can be useful because normal images of the striatum showed by SPECTDaTSCAN exclude neurodegenerative parkinsonism.

The Consensus Statement on the Classification of Tremors was published under the auspices of the International Parkinson and Movement Disorder Society (IPMDS) in 2018. The classification proposed in this document is based on two 
axes: clinical features and aetiology. Among the clinical features, the anatomical distribution of tremor and activation conditions, the activating factors are of key importance. We decided to use the approach proposed in the Consensus Statement on the Classification of Tremors to reanalyse retrospectively the evaluation of tremor and to reconsider the indications for SPECT-DaTSCAN in 24 consecutive patients with isolated tremor of upper limbs. We did not find patients with isolated tremor of both upper and lower limbs or tremor limited to lower limbs in our material.

Rest as well as action (kinetic and/or postural) tremor may occur in ET and dystonia, but also in neurodegenerative PS, including PD, multiple system atrophy (MSA) and progressive supranuclear palsy (PSP) (Armstrong et al., 2013; Fekete and Jankovic, 2011; Gilman et al., 2008; Jankovic et al., 1999; Litvan et al., 1996; Schwingenschuh et al., 2010). Rest tremor may be present in about $20 \%$ of ET patients, usually in elderly ones (Cohen et al., 2003), and such cases should be classified as "ET plus" (Bhatia et al., 2018). On the other hand, postural and kinetic tremor may be observed in up to $60 \%$ of patients with PD (Jankovic et al., 1999; Meara et al., 1999; Thenganatt and Jankovic, 2014).

Action (kinetic and postural) tremor has similar features in neurodegenerative parkinsonism and in ET or ET-like syndromes. However, rest tremor in PS has characteristic features which are not observed in other tremor syndromes: 4-7-Hz frequency, "pill-rolling" sign, disappearance when the muscles are activated voluntarily or achieving the goal. Moreover, tremor is easier to observe while the patient is moving another part of the body (Jankovic et al., 1999; Papengut et al., 2013).

According to the Consensus Statement, a definition of ET requires at least a 3-year history of tremor. The assumption was made that during this period the probability of developing other symptoms decisive for changing the diagnosis from ET to another tremor syndrome is most likely. Isolated tremor of duration shorter than 3 years should be labelled as "indeterminate tremor." In addition, the proposed definition of ET includes the condition of the presence of bilateral action tremor.

There were 12 subjects (Group I and IV) presenting isolated action and rest tremor in our material. The result of SPECTDaTSCAN was abnormal in a single case with tremor limited to one side and in 1 out of 11 cases with bilateral signs. These results confirm that early occurrence of bilateral action tremor, i.e. before the lapse of 3 years, is likely to support the diagnosis of ET. At the same time, our results showed that the coexistence of resting tremor with bilateral action tremor is not associated with a significant probability of PD. In patients with the diagnosis of tremor-dominant PD, tremor did not respond to levodopa.

It should be noted that in our material subjects with rest tremor were over-represented, because its presence regardless of the occurrence of other types of tremors - was a probable factor determining the referral of these patients for SPECT-DaTSCAN.
Patients with the combination of postural and kinetic tremor, both bilateral (Group II) and unilateral (Group III), had normal SPECT-DaTSCAN. Among the unilateral cases (all with duration of tremor $<3$ years), a neurological examination allowed a diagnosis of dystonic tremor, while the other two cases were classified as "indeterminate tremor." SPECT revealed an abnormality within the dopaminergic nigrostriatal system in all five patients (Group V) who presented rest and postural tremor, unilaterally or bilaterally. In this group, MSA was suspected in one case, while the remaining patients were diagnosed with PD. Rest and postural tremor in subjects with a diagnosis of PD did not improve after the administration of levodopa.

Early SPECT-DaTSCAN in patients with isolated tremor brings limited benefits. Certainly, the aetiology of the disease process is explained, but further benefits are doubtful. Undoubtedly, the abnormal SPECT-DaTSCAN result means that we can avoid the treatment attempts according to therapeutic recommendations in ET.

\section{CONCLUSIONS}

1. The probability of PD in patients with rest and action (kinetic plus postural) tremor, both unilateral and bilateral, is low. It is also low in subjects with postural and kinetic tremor.

2. In cases of a combination of rest and postural tremor (both unilateral and bilateral), the likelihood of neurodegenerative parkinsonism is high. However, early in the disease ( $<3$ years), the possibility of differentiation between individual PS is very limited.

3. Performing SPECT-DaTSCAN in isolated cases of tremor with a high risk of $\mathrm{PD}$ avoids the unnecessary use of drugs recommended in the therapeutic algorithms applicable in ET.

\section{Conflict of interest}

The authors do not report any financial or personal connections with other persons or organisations which might negatively affect the content of this publication and/or claim authorship rights to this publication.

\section{References}

Albanese A, Bhatia K, Bressman SB et al.: Phenomenology and classification of dystonia: a consensus update. Mov Disord 2013; 28: 863-873.

Armstrong MJ, Litvan I, Lang AE et al.: Criteria for the diagnosis of corticobasal degeneration. Neurology 2013; 80: 496-503.

Berardelli A, Wenning GK, Antonini A et al.: EFNS/MDS-ES/ENS [corrected] recommendations for the diagnosis of Parkinson's disease. Eur J Neurol 2013; 20: 16-34.

Bhatia KP, Bain P, Bajaj N et al.; Tremor Task Force of the International Parkinson and Movement Disorder Society: Consensus Statement on the Classification of Tremors. From the task force on tremor of the International Parkinson and Movement Disorder Society. Mov Disord 2018; 33: 75-87.

Cohen O, Pullman S, Jurewicz E et al.: Rest tremor in patients with essential tremor: Prevalence, clinical correlates, and electrophysiologic characteristics. Arch Neurol 2003; 60: 405-410. 
Deuschl G, Bain P, Brin M: Consensus statement of the Movement Disorder Society on Tremor. Ad Hoc Scientific Committee. Mov Disord 1998; 13 Suppl 3: 2-23.

Fekete R, Jankovic J: Revisiting the relationship between essential tremor and Parkinson's disease. Mov Disord 2011; 26: 391-398.

Gilman S, Wenning GK, Low PA et al.: Second consensus statement on the diagnosis of multiple system atrophy. Neurology 2008; 71: 670-676.

Jankovic J, Schwartz KS, Ondo W: Re-emergent tremor of Parkinson's disease. J Neurol Neurosurg Psychiatry 1999; 67: 646-650.

Kim YJ, Ichise M, Ballinger JR et al.: Combination of dopamine transporter and D2 receptor SPECT in the diagnostic evaluation of PD, MSA, and PSP. Mov Disord 2002; 17: 303-312.

Litvan I, Mangone CA, McKee A et al.: Natural history of progressive supranuclear palsy (Steele-Richardson-Olszewski syndrome) and clinical predictors of survival: a clinicopathological study. J Neurol Neurosurg Psychiatry 1996; 60: 615-620.

Louis ED: Twelve clinical pearls to help distinguish essential tremor from other tremors. Expert Rev Neurother 2014; 14: 1057-1065.

Marshall V, Grosset DG: Role of dopamine transporter imaging in the diagnosis of atypical tremor disorders. Mov Disord 2003; 18 Suppl 7: S22-S27.
Meara J, Bhowmick BK, Hobson P: Accuracy of diagnosis in patients with presumed Parkinson's disease. Age Ageing 1999; 28: 99-102.

Papengut F, Raethjen J, Binder A et al.: Rest tremor suppression may separate essential from parkinsonian rest tremor. Parkinsonism Relat Disord 2013; 19: 693-697.

Perju-Dumbrava LD, Kovacs GG, Pirker S et al.: Dopamine transporter imaging in autopsy-confirmed Parkinson's disease and multiple system atrophy. Mov Disord 2012; 27: 65-71.

Schwingenschuh P, Ruge D, Edwards MJ et al.: Distinguishing SWEDDs patients with asymmetric resting tremor from Parkinson's disease: a clinical and electrophysiological study. Mov Disord 2010; 25: 560-569.

Stankovic I, Krismer F, Jesic A et al.; Movement Disorders Society MSA (MODIMSA) Study Group: Cognitive impairment in multiple system atrophy: a position statement by the Neuropsychology Task Force of the MDS Multiple System Atrophy (MODIMSA) Study Group. Mov Disord 2014; 29: 857-867.

Thenganatt MA, Jankovic J: Parkinson disease subtypes. JAMA Neurol 2014; 71: 499-504.

Vlaar AM, de Nijs T, Kessels AG et al.: Diagnostic value of ${ }^{123} \mathrm{I}$-ioflupane and ${ }^{123}$ I-iodobenzamide SPECT scans in 248 patients with parkinsonian syndromes. Eur Neurol 2008; 59: 258-266. 